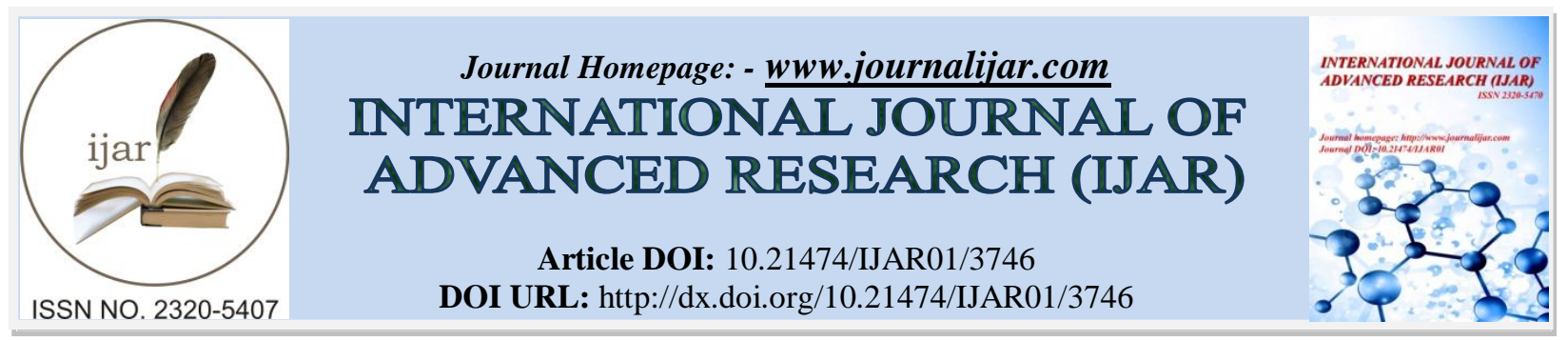

RESEARCH ARTICLE

\title{
STUDY OF SOME SELECTED AQUATIC AND SEMI-AQUATIC FAUNA OF BAANGANGA WETLANDS, HARIDWAR (UTTARAKHAND, INDIA).
}

Bahuguna Archana ${ }^{1}$, Sharma Indu ${ }^{2}$ Gopal Sharma ${ }^{3}$, Hasko Nesemann ${ }^{3}$ and Kumar Parmod ${ }^{1}$.

1. Northern Regional Centre, Zoological Survey of India, 218, Kaulagarh Road, DehraDun, Uttarakhand 248195.

2. High Altitude Regional Center, Zoological Survey of India, Solan, Himachal Pradesh Central University of Bihar, BIT, campus Patna 800014.

3. Zoological Survey of India, Gangetic plains Regional Centre, Patna 800016.

\section{Manuscript Info}

(n........................

Manuscript History

Received: 16 January 2017

Final Accepted: 01 February 2017

Published: March 2017

Key words:-

Baanganga wetland, freshwater turtles, anurans, pisces, ecological study, water analysis.

\section{Abstract}

Baanganga, the riverine wetland lies between Hastinapur Wildlife Sanctuary in Uttar Pradesh and Jhilmil Jheel Conservation Reserve, in Uttarakhand is considered a major habitat for wintering waterfowl. The habitat, known for swamp deer and hog deer and also for aquatic and semi aquatic fauna, is deteriorating as revealed by the analysis of physico-chemical properties of water. The present study recorded the occurrence of four species of freshwater turtles, marsh crocodile, three amphibians and 18 species of fishes in the Baanganga wetland. Freshwater turtle, Morenia petersi recorded from the area is a new record for the State. We suggest measures for conservation of these wetlands.

Copy Right, IJAR, 2017,. All rights reserved.

\section{Introduction:-}

Wetlands harbor variety of fauna that inhabit terrestrial-semi-aquatic and aquatic environments. Baanganga wetland, Indrishpur village in Haridwar district lies between Hastinapur Wildlife Sanctuary in Uttar Pradesh and Jhilmil Jheel Conservation Reserve in Uttarakhand. It represents riverine wetland ecosystem (Fig.1). The construction of a dam across river Ganga, near Baanganga and other anthropogenic activities have led to the conversion of channel into isolated water bodies. These wetlands are still considered as major habitat for wintering waterfowl, though they are surrounded by large agricultural fields and human settlements (Adhikari 2008). The Indo-Gangetic plain and the Terai region have diverse Chelonian fauna with 20 species of freshwater turtles (Das 2002, Rao 1990). The present study describes the occurrence freshwater turtles, amphibians and fishes based on collection and sightings in and around Baanganga. Water quality of the area and suitability for aquatic fauna is also described.

\section{Material And Methods:-}

Study area: Baanganga wetland $\left(78^{\circ} 2^{\prime} 43^{\prime \prime} \mathrm{E}\right.$ to $78^{\circ} 2^{\prime} 15^{\prime \prime} \mathrm{E}$ and $29^{\circ} 44^{\prime} 5^{\prime \prime} \mathrm{N}$ to $\left.29^{\circ} 36^{\prime} 01^{\prime \prime} \mathrm{N}\right)$ is located $60 \mathrm{~km}$. southwest of Haridwar on Laksar-Purkaji road, and it has about $10 \mathrm{~km}^{2}$ water spread area. Land use and land cover include; water bodies (55\%), marsh (4\%), islands (15\%), moist shores (8\%) and upland (18\%) (Adhikari, 2008, Fig 2-4).

Monthly surveys were conducted along the Baanganga River covering seven localities (Table 1) during May -Sep 2008 to 2010. The wetland was divided into five land use categories: water bodies, marshy area, islands, moist

Corresponding Author:- Bahuguna Archana. 
shores and upland (Adhikari 2008) and surveyed randomly for freshwater turtles, amphibian and fishes. Enquiries were also made on the occurrence of taxa studied.

A minimum of 10 water samples were collected from each (eight) water bodies for analysis (Table 6, 7). The ambient temperature of the atmosphere and of surface water was taken by using digital thermometer. Dissolved oxygen of water was calculated following/ NIH (1987-1988) and electrical conductivity was determined following method given by Jackson (1962). The levels of calcium, magnesium, chloride and bicarbonate were assessed titrimetically (Jackson 1962a, b, c, d).

Mollusca were collected qualitatively together with other fauna using a plastic hand-net of $1 \mathrm{~mm}$ mesh size and hand picking method directly from the habitat. Larger specimens of the samples were pre-identified in the field and preserved in $15 \%$ ethyl alcohol to avoid hardening and contraction, later they were transferred into $70 \%$ ethyl alcohol. The material is deposited in the Zoological Survey of India, Northern Regional Centre, Dehradun. Identification was done with the help of Preston (1915), Subba Rao (1989) and Ramakrishna \& Dey (2007).

\section{Results and Discussion:-}

Fauna: Molluscs, fishes and amphibia are known to be the major food for many freshwater turtles (Tikader and Sharma 1985). The aquatic Mollusca fauna associated with the investigated habitats comprise 8 snails (Class Gastropoda) and 6 shells (Class Pelecypoda or Bivalvia). All records are relatively large-sized species of riverine and wetland or lake habitats. These are the most frequently found and common mollusks of the Gangetic Plains including the Himalayan foothills and the Kumaon Lakes (Prashad, 1922; Nesemann et al., 2003-2007) (Table 2).

The family Viviparidae is represented with two species. The most common snail in different types of running and stagnant water bodies was Bellamya bengalensis with fifteen localities during the present field studies. The second much smaller Viviparidae Idiopoma dissimilis was found in three localities and this species was limited on stagnant water bodies.Among the air-breathing snails, the two species Lymnaea acuminata with seven localities and Indoplanorbis exustus with five localities were distributed in all types of water bodies with shallow zones and presence of submerged aquatic macrophytes including paddy fields as well as the shorelines of lakes and reservoirs in the Himalayan middle mountains (Table 2).

The freshwater mussels were found in two rivers with six widely distributed species of the Indian subcontinent, e.g. Parreysia favidens, Radiatula and the clam shell Corbicula striatella. The Unionidae were identified with results of Nesemann et. al (2003) and the updated species catalogue of Haas (1969), Graf and Cummings (2007). The presence of a number of large bivalves species always indicates stable ecological conditions with fairly good sediment quality. The larvae or glochidia need different host fishes to complete metamorphosis into a young freshwater mussel.

The pollution tolerant Physidae Haitia mexicana is a true invasive species or neozoan that reached the northern Indian subcontinent by introduction to the capitals as the main centers of aquarium trade with plants and substrate. Haitia mexicana started rapid spreading from Delhi after 1994 (Surya Rao et al. 1997), reaching Allahabad in the year 1998 and Patna in the year 2000 (Sinha et al. 2003). It simultaneously colonized the Bagmati Kosi River system starting from Kathmandu after 1994. Nowadays Haitia mexicana is a widespread species of various polluted and degraded water bodies. The species remains absent from most natural habitats which have developed a rich diversified native fauna. Thus $\mathrm{H}$. mexicana is always an indicator for direct anthropogenic impact. However in the present study there was no record of this species in any of the water body studied indicating that the area is still suitable for aquatic and semi aquatic fauna but small measures can be taken to improve the quality of the habitat.

Eighteen species of fishes belonging to 14 genera, 9 families and 3 orders were observed during this study (Table3). The heterogeneity of the wetlands could be one of the reasons for the observed diversity (Kumar, 2007).

Three species of anurans, Fejervarya sahydrensis (Annandale); Syhadra frog, Euphlyctis cyanophlyctis (Schneider) and Indian bull frog, Hoplobatrachu stigerinus (Daudin) were collected during this study (Table 4). The cricket frog has been reported to be available in small hill streams and water logged areas near paddy fields. The population of the species is denser in eastern parts of the district Dehradun (Ray 1998). Zakerana were split off from Fejervarya in 2011. This was the culmination of recognizing that Fejervarya (as known before) was paraphyletic and consisted of two different groups; this recognition had already developing some years before. The sister taxon of Zakerana is 
Sphaerotheca (Frost 2014, Howalder 2011). Fejervarya, as currently defined, has a more eastern distribution than the southern Asiatic Zakerana, from eastern India eastwards. (Frost 2014). They are sometimes known as the South Asian cricket frogs.

Euphlyctis cyanophlyctis was the most common anuran recorded from the area. It can tolerate considerable amount of contamination and organic pollution in temporary water pools (Ray1998), (Table 4).

Four species of freshwater turtles; Lissemys punctata andersonii (Webb), Pangshura tecta (Gray), Pangshura tentoria circumdata (Gray) and Morenia petersi (Anderson) were observed (Table 4, Fig. 8, 9). Lissemys punctata andersonii and Pangshura tecta are listed under Schedule- I of the Wildlife (Protection) Act, 1972, and Pangshura tentorian circumdata and Morenia petersi are new distributional records for Uttarakhand state (Bahuguna 2009, Bahuguna 2010) (Figs 6-9). Rawat and Pandav (2006) also reported three species; Geoclemys hamiltonii, Kachuga kachuga and Lissemys punctata from these wetlands and all are listed in Scheduled I of the IWPA (Table 5).

Marsh crocodile (Crocodylus palustris Lesson) was observed during this study and also reported in the past (Rawat and Pandav 2006, Rashtriya Sahara 2009). The crocodiles were reported to often enter the human settlements near Laksar in Ajitpur area. The distribution of crocodiles in Uttarakhand is restricted to Corbett Tiger Reserve and Baanganga wetlands.

\section{Physico- Chemical Parameters:-}

Temperature: Mean surface temperature of the various water bodies ranged from $25^{\circ}$ to $30^{\circ} \mathrm{C}$ during $\mathrm{May}-$ September 2008 and 2009 (at $1200 \mathrm{hrs}-1230 \mathrm{hrs}$ ). The highest ambient temperature (39 $\mathrm{C}$ ) was recorded during May and June.

The increase in temperature in water leads to speeding up of chemical reactions and reduced solubility of gases (Hem 1989, NIH 1987-1988). Continuous depletion of ground water reservoirs and deterioration of quality in Haridwar is reported by Rao \& Kumar (2002). The increase in temperature in the area must be due to recent spate of urbanization, increased vehicular pollution, regular incoming of pilgrims to Haridwar and ever increasing population in Haridwar. This increase in temperature can deteriorate the conditions of some of the water bodies (2-3 meters depth, Nainpur) harboring the important aquatic, semi aquatic fauna and water birds (Figs 6, 7).

pH and electrical conductivity : The $\mathrm{pH}$ recorded in the present study (Table 6) varied from 7.02 to 8.14 (in Lalpur near to Stone crusher unit). The range of $\mathrm{pH}$ for freshwater was within the permissible limit of BIS 10500 (1991). Electrical conductivity of water corresponds to the total concentration of dissolved compounds (electrolyte). It was noted to be varying from 0.191 to $0.588 \mathrm{ds} / \mathrm{m}$. Highest has been noted to be in water bodies near to human settlements

Dissolved oxygen: Dissolved oxygen varied from 3 to $4 \mathrm{ppm}$ in the present study. DO for healthy water has been recommended to be $>6$ ppm by BIS 1991(Table 5).

Calcium: In the present study, Calcium concentration from all localities ranged from 24-76 ppm, highest Nainpur i.e. $64 \mathrm{ppm}$, whereas for Lalpur it was $48 \mathrm{ppm}$ (Table 7). Calcium concentrations in natural waters are typically less than $15 \mathrm{mg} \mathrm{l}^{-1}$ (NIH 1987-88). For waters associated with carbonate rich rocks, level may reach $30-100 \mathrm{mg} \mathrm{l}^{-1}$. Cremation sites near Nainpur (Fig 4) and stone crusher facility in Lalpur area (Fig 2) and intense human activities near Shahpur might have led to increased level of calcium in the water sample. It has been reported that acidic rainwater can increase the leaching of calcium from soil (Hem 1989, NIH. 1987-1988).

Magnesium: As noted, the magnesium concentration ranged from $12.0 \mathrm{ppm}$ to $48 \mathrm{ppm}$, which is within the range of natural conditions. Natural levels of magnesium in freshwater may range from 1 to $100 \mathrm{mg}^{-1}$. Magnesium occurs in many organomettalic compounds and in organic matter since it is an essential element for living organisms. Although magnesium is used in many industrial processes these contribute relatively little to the total magnesium in surface waters (EIFAC 1964-90, ISO 1984, Hem 1989, WHO 1984a, 1984b).

Carbonate: Carbonate concentration in water ranged from 6 to $18 \mathrm{mg} \mathrm{l}^{-1}$., it was noted to be nil at Nainpur and Tada Bhagmal localities (Table 6). Carbonate is uncommon in natural surface waters because they rarely exceed $\mathrm{pH} 9$, whereas the groundwater can be more alkaline and may have concentrations of carbonate up to $10 \mathrm{mg}$ per liter. 
Bicarbonate concentration in surface water is usually less than $500 \mathrm{mg} \mathrm{l}^{-1}$ (WHO 1984a, 1984b). In the present study, it was noted to be within the range and was the dominating anion present in surface water (Table 7).

Chloride: In the present observations it was noted to be very high i.e. of the 56.8 to $78.1 \mathrm{ppm}$. In freshwater, chloride concentrations are usually lower than $10 \mathrm{mg} \mathrm{l}^{-1}$ and sometimes less than $2 \mathrm{mg} \mathrm{l}^{-1}$ (APHA 1989, Hem 1989). Higher concentrations can occur near sewage and other waste outlets, irrigation drains, salt water intrusions, in arid areas and in wet coastal lines. In the present study, it seemed to be mainly through irrigation drains and waste outlets. As chloride is frequently associated with sewage, it is often incorporated into assessments as an indication of possible faecal contamination or as a measure of the extent of the dispersion of sewage discharge in water bodies (APHA 1989; Bestemyanov and Krotov, 1985; CEC 1976).

The physicochemical parameters recorded depicted that for the fishes $\mathrm{pH}$ was optimum. The value of dissolved oxygen in the present study varied from 3 to $4 \mathrm{mg} / \mathrm{l}$. Oxygen plays a vital role to regulate the metabolic processes and is indicator of aquatic productivity. For average, good productivity dissolved oxygen should have concentration $>5 \mathrm{mg} / \mathrm{l}$ (Banerjee 1967) and thus the D.O. recorded is less for the survival of the fish. The chloride level $(56.8$ to $78.1 \mathrm{mg} / \mathrm{l})$ was noted to be too high depicting that the water might be leading towards eutrophication (CEC 1976, Jairam1999).

Human activities around and in the area like cleaning cattle's, taking bath and discharge of remains of human cremationin small water bodies were affecting the health of the water as revealed by physical and chemical analysis of water (Tables 6,7). Agriculture practices around the area were also affecting the water level in remnant habitats as the drainage through water pumps were done and still going on to increase the land area and for irrigation purpose. The upland and moist shores of the study area were noted to be utilized for agriculture. The area was also exploited to collect stone for stone crusher unit present in the area. The local enquiries revealed the presence of channel full of water till 1980 in the same locality meeting Ganga, thus called Baanganga, but the construction of barrages/ dam on Ganga led to decrease in the water level in the channel, thus produced different land categories (Adhikari, 2008). Rao (1998) extensively surveyed from Rishikesh to Kanpur and reported 12 species of freshwater turtles. Localities near Baanganga (Haridwar) were surveyed by Adhikari (2008) and Kumar (2007) for the study of vegetation types and fish fauna. They reported that the study area harbored many islands, varying in shape and size, which remainec underwater during the rainy season and provided a good habitat to various plant taxa, birds (resident as well as migratory) and animals mainly Swamp deer, Cervus duvauceli duvauceli Cuvier, a critically endangered species and Hog deer, Axis porcinus(Zimmermann).

Activities like sand mining, agriculture, reclamation of wetlands and riparian areas, alternation of rivers for irrigation and generation of hydroelectric power, pollution, siltation, eutrophication and intensive fishing have been reported to cause the killing of turtles, affecting their nesting (Bhupathy and Chaudhury 1995, Sharma 1998, Rao 1998). Surveys to the present study area since May 2008-September 2010 unfolded the deteriorating situation of the habitat for aquatic and semi-aquatic fauna. Main factors, which have affected the habitat, are: barrage/dam construction nearest to habitat, increase in human activities including agriculture, use of open water bodies for cattle and human bath, cremation ground including weed proliferation in many water bodies. The increase in ambient atmospheric temperature that resulted in the low level of water in many small water bodies causing death of fishes and other aquatic fauna as observed during the surveys.

Rao (1998) undertook extensive survey in Ganga River $(645 \mathrm{~km})$ at a stretch between Rishikesh to Kanpur to know the status of freshwater turtles and reported 12 species of freshwater turtles under seven genera. He observed that all the way from Rishikesh to Kanpur most of the Ganga Ghats have religious importance. Large numbers of the pilgrims take holy bath, do cremation and post cremation activities and thus become a major source of pollution to the river; large number of factories like IDPL, BHEL, sugar, chemicals, fertilizers, engineering, cotton and tanneries are situated on the bank of the river. The natural flow of the Ganga River has been checked due to construction of hydro-power barrages up-stream at Rishikesh, Haridwar, Bijnor and Narora. Two barrages have been constructed at Haridwar and Bijnor for irrigation purpose through Upper Ganga canal and Madhya Ganga Canal, respectively (Rao 1985). The present study although limited to a small area of 8-10 km has significant importance as the area still has freshwater turtle species in various water bodies and they need conservation and protection, as lowering the water levels and scarcity of the food might increase the mortality rate besides exposing them to the danger of illegal trade. Local people were though aware of the legal protection of the freshwater turtles were not 
able to differentiate Scheduled and unscheduled species. Local enquiry revealed that the people from outside were coming to the area and asking for particular species of freshwater turtles for medicine.

Illegal trade of freshwater turtles is a global problem, involving many of the developing countries. There is a demand of turtles in China, Singapore and Hong Kong markets. In India, the illegal trade of turtles is going on and the most common routes are from Kanpur to Kolkata market. Uttarakhand State earlier rich in biodiversity of turtles but recently the population of turtles has now been found to be restricted (Husain and Ray 1995), thus indicating threats to the population of turtles and tortoises in the State. There is an urgent need for the management to conserve the habitat and the species.

\section{Conclusion:-}

Water bodies in Baanganga wetlands of Haridwar, Uttarakhand are not in healthy conditions. This river is also passing through the conservation area Jhilmil Jheel, thus needs special attention for habitat management. Available oxygen, adequate nutrients and absence of toxic chemicals are essential factors for growth and reproduction for aquatic and semi-aquatic fauna. In the present study increasing atmospheric temperature, increased $\mathrm{pH}$ in some water bodies, low oxygen in water, high level of chloride ions were noted to be harmful for the habitat of aquatic and semi aquatic fauna still thriving in the area. Many scheduled (under IWPA) species were found to be present in the area including turtles, crocodile and mammals, indicating the importance of the area. Low level of water during summer and increased pressure due to anthropogenic activities were noted to be increasing the threat to their survival and make them easy target of poaching.

\section{Management plan for the area:}

1. The water body in Nainpur locality can be a good habitat for aquatic and semi aquatic fauna after implementation of some management measures like: removal of weeds, pumping air, shifting cremation ground and involvement of local people for management of habitat, reintroduction of aquatic-semi aquatic fauna from deteriorating habitat to habitat in Nainpur.

2. Afforestation programmes around the area should be initiated to improve the habitat and to control the rising temperature.

3. Strong actions are required to conserve the threatened and endangered species as some of them may reach the threshold of critical endangerment.

4. Involvement of local people: generate awareness among local community about the importance of fauna residing in the area; involve them in reintroduction programmes, afforestation programme. Local people and turtle trappers should be involved in various surveys to get information of illegal trade.

Table 1:- Land types present

\begin{tabular}{|l|l|l|}
\hline S.No. & \multicolumn{1}{|c|}{ Localities } & \multicolumn{1}{|c|}{ Land types } \\
\hline $\mathbf{1}$ & Shahpur & $\begin{array}{l}\text { Small water bodies 20\%, upland, agriculture area covering } 60 \\
\% \text { of the area, human settlements 20\% }\end{array}$ \\
\hline $\mathbf{2}$ & TandaBhagmal & $\begin{array}{l}\text { Few water bodies 10\%, agriculture area 55 \% and human } \\
\text { settlement 20\% }\end{array}$ \\
\hline $\mathbf{3}$ & Lalpur & $\begin{array}{l}\text { Open water bodies 30\%, } \\
\text { Agriculture 50\%, rest other types }\end{array}$ \\
\hline $\mathbf{4}$ & Nainpur & $\begin{array}{l}\text { Open water bodies 50\%, marshy area } \\
20 \%, \text { upland10\%,agriculture 10\%,human settlements 10\% }\end{array}$ \\
\hline $\mathbf{5}$ & Indreshpur & $\begin{array}{l}\text { Open water bodies 10\%, agriculture 55\%, rest human } \\
\text { settlements }\end{array}$ \\
\hline $\mathbf{6}$ & Ranjitpur & $\begin{array}{l}\text { Open water body 75\% (near to Ganga bank), agriculture 25\%, } \\
\text { rest human settlement }\end{array}$ \\
\hline $\mathbf{7}$ & Bhikampur & $\begin{array}{l}\text { Open water body 25\%,agriculture area 50\%, human } \\
\text { settlements 25\% }\end{array}$ \\
\hline
\end{tabular}


Table 2:- Mollusca diversity in Baanganga area

\begin{tabular}{|c|c|c|c|c|c|}
\hline $\begin{array}{l}\text { Sl. } \\
\text { No. }\end{array}$ & Name of Place & $\begin{array}{l}\text { Date of } \\
\text { Collection }\end{array}$ & Species & $\begin{array}{l}\text { No. of } \\
\text { specimen }\end{array}$ & Identified by \\
\hline \multirow[t]{2}{*}{1.} & $\begin{array}{ll}\text { Near Solani } & \text { Bridge } \\
\text { Dist.Haridwar } & \\
\end{array}$ & 9.11 .2009 & Gastropoda & & $\begin{array}{l}\text { Dr. G. Sharma/ } \\
\text { Dr.H.Nesemann }\end{array}$ \\
\hline & & & Bellamya bengalensis & 19 & -do- \\
\hline \multirow[t]{8}{*}{2.} & Solani River, Haridwar & 25.06 .2010 & Gastropoda & 2 & -do- \\
\hline & & & Lymnae accuminata & & \\
\hline & & & Bellamya bengalensis & 3 & -do- \\
\hline & & & Pelecypoda & & \\
\hline & & & Parreysia (favidens)viridula & 1 & -do- \\
\hline & & & Radiatula occata & 9 & -do- \\
\hline & & & Radiatula caerulia & 1 & -do- \\
\hline & & & Lamellidens marginalis & 1 & -do- \\
\hline \multirow[t]{4}{*}{3} & $\begin{array}{l}\text { Nainpur( From large open water } \\
\text { body) Haridwar }\end{array}$ & 11.10 .2008 & Gastropoda & & \\
\hline & & & Indoplanorbis exustus & 2 & - do- \\
\hline & & & Bellamya bengalensis & 2 & -do- \\
\hline & & & Idiopoma dissimilis & 20 & -do- \\
\hline \multirow[t]{4}{*}{4} & $\begin{array}{l}\text { Haridwar and around( then } \\
\text { away from Solani River) }\end{array}$ & 25.02 .2010 & Gastropoda & & \\
\hline & & & Lymnaea accuminata & 3 & -do- \\
\hline & & & Radix luteola & 1 & -do- \\
\hline & & & Bellamya bengalensis & 17 & -do- \\
\hline 4 & Kanpur Ganga (U.P.) & 19.04 .2011 & Gastropoda & & \\
\hline \multirow[t]{3}{*}{5} & $\begin{array}{l}\text { Nainpur( From large open water } \\
\text { body) Haridwar }\end{array}$ & 11.10 .2008 & Gastropoda & & \\
\hline & & & Indoplanorbis exustus & 2 & -do- \\
\hline & & & Bellamya bengalensis & 10 & -do- \\
\hline \multirow[t]{3}{*}{7.} & Baan Ganga, Nainpur, Haridwar & 18.06 .2009 & Gastropoda & & \\
\hline & & & Bellamya bengalensis & 16 & -do- \\
\hline & & & Lymnaea accuminata & 1 & -do- \\
\hline \multirow[t]{2}{*}{8} & Khatoli (Pond) Haridwar & 29.07 .2009 & Gastropoda & & \\
\hline & & & Bellamya bengalensis & 79 & -do- \\
\hline \multirow[t]{4}{*}{9.} & $\begin{array}{l}\text { Baan Ganga near village Tanda, } \\
\text { Haridwar }\end{array}$ & 14.05 .2008 & Gastropoda & & \\
\hline & & & Bellamya bengalensis & 10 & -do- \\
\hline & & & Indoplanorbis exustus & 2 & -do- \\
\hline & & & Lymnaea accuminata & 1 & -do- \\
\hline \multirow[t]{3}{*}{10.} & Ranjitpur (Haridwar) & 17.10 .2008 & & & \\
\hline & & & Idiopoma dissimilis & 6 & -do- \\
\hline & & & Radix luteola & 1 & -do- \\
\hline \multirow[t]{4}{*}{11} & $\begin{array}{l}\text { Nainpur near Luksar (Dist } \\
\text { Haridwar). }\end{array}$ & 30.12 .2008 & Gastropoda & & \\
\hline & & & Bellamya bengalensis & 6 & -do- \\
\hline & & & Indoplanorbis exustus & 1 & -do- \\
\hline & & & Lymnaea accuminata & 2 & -do- \\
\hline \multirow[t]{5}{*}{12.} & Lalpur (Near Haridwar) & 14.11 .2008 & Gastropoda & & \\
\hline & & & Bellamya bengalensis & 5 & -do- \\
\hline & & & Idiopoma dissimilis & 3 & -do- \\
\hline & & & Indoplanorbis exustus & 1 & -do- \\
\hline & & & Lymnaea accuminata & 1 & -do- \\
\hline
\end{tabular}




\begin{tabular}{|c|l|l|l|l|l|}
\hline 13. & Solani River Fc no.3 & 15.09 .2009 & Pelecypoda & & \\
\hline & & & Radiatula occata & 1 & -do- \\
\hline 14. & Nainpur : Haridwar \& around & 18.07 .2008 & Gastropoda & & \\
\hline & & & Bellamya bengalensis & 1 & -do- \\
\hline & & & Pila globossa & 1 & -do- \\
\hline & & & Lymnaea accuminata & 1 & -do- \\
\hline & & & Indoplanorbis exustus & 6 & -do- \\
\hline
\end{tabular}

Table 5:- List of species of freshwater turtles from various localities.

\begin{tabular}{|c|c|c|c|c|}
\hline S.No & Species & Localities & Common Name & $\begin{array}{l}\text { Category under } \\
\text { IWPA 1972 }\end{array}$ \\
\hline 1 & Pangshura tecta(Gray) & $\begin{array}{l}\text { Shahpur, } \\
\text { TandaBhagmal, Lalpur, } \\
\text { Nainpur, Indreshpur, } \\
\text { Ranjitpur, }\end{array}$ & Indian roofed turtle & Schedule- I \\
\hline 2 & $\begin{array}{ll}\text { Pangshura } & \text { tentoria } \\
\text { circumdata (Gray) } & \\
\end{array}$ & Ranjitpur, Shahpur & $\begin{array}{lll}\text { Circled } & \text { Indian } & \text { tent } \\
\text { turtle } & & \\
\end{array}$ & Not listed \\
\hline 3 & $\begin{array}{l}\text { Lissemys punctata } \\
\text { andersonii( }(\mathrm{Webb})\end{array}$ & $\begin{array}{l}\text { TandaBhagmal, Lalpur, } \\
\text { Nainpur, Ranjitpur }\end{array}$ & $\begin{array}{l}\text { Indian flap shelled } \\
\text { turtle }\end{array}$ & Schedule- I \\
\hline 4 & Morenia petersi (Anderson) & Bhikampur & Indian eyed turtle & Not listed \\
\hline
\end{tabular}

Table 3:- List of fishes

\begin{tabular}{|c|c|c|c|c|c|c|}
\hline \multicolumn{7}{|c|}{1 Order Cypriniformes } \\
\hline \multicolumn{4}{|c|}{ Family 1 Cyprinidae $\quad$ Subfamily Ras } & borin & & \\
\hline S.No.. & Species & \multirow{2}{*}{\multicolumn{2}{|c|}{$\begin{array}{l}\text { Locality } \\
\text { Ranjitpur village, Ganga River- } \\
\text { 19exs,Bann Ganga, Near Village } \\
\text { Tanda Bhagma-01ex, Lalpur, } \\
\text { Luxar, dist. Haridwar-01ex }\end{array}$}} & \multicolumn{2}{|c|}{ Common Name } & Local Name \\
\hline 1 & Daniorerio (Hamlton.1822) & & & \multicolumn{2}{|c|}{ Zebrafish } & Chahal \\
\hline 2 & $\begin{array}{ll}\begin{array}{l}\text { Esomus } \\
\text { (Hamilton.1822) }\end{array} & \text { danricus } \\
\end{array}$ & \multicolumn{2}{|c|}{ Nainpur, Luxar-06exs } & \multicolumn{2}{|c|}{ Flying barb } & Chiddullu \\
\hline \multirow[t]{2}{*}{3} & $\begin{array}{l}\text { Rasboradaniconius } \\
\text { (Hamilton.1822) }\end{array}$ & \multicolumn{2}{|c|}{$\begin{array}{l}\text { Ranjitpur village, Ganga River-12exs, } \\
\text { Bann Ganga, Near Village Tanda } \\
\text { Bhagma, Nainpur, Luxar-02exs, } \\
\text { Nainpur, Luxar-02exs }\end{array}$} & \multicolumn{2}{|c|}{ Blacklinerasbora } & Chinoodolah \\
\hline & \multicolumn{6}{|c|}{ Subfamily Cyprininae } \\
\hline S.No.. & Species & Locality & \multicolumn{2}{|c|}{ Common Name } & \multicolumn{2}{|c|}{ Local Name } \\
\hline 1 & $\begin{array}{l}\text { Puntiuschola } \\
\text { (Hamilton..1822) }\end{array}$ & $\begin{array}{lr}\text { Ranjitpur } & \text { village, } \\
\text { Ganga } & \text { River-01ex, } \\
\text { Nainpur, Luxar-12exs }\end{array}$ & \multicolumn{2}{|c|}{ Chola barb } & \multicolumn{2}{|c|}{ Pothi } \\
\hline 2 & $\begin{array}{l}\text { Puntiussophore (Hamilton. } \\
\text { 1822) }\end{array}$ & $\begin{array}{l}\text { Bann Ganga near } \\
\text { Village Shahpur, } \\
\text { Sitakhera-03exs, } \\
\text { Nainpur, Luxar-01ex }\end{array}$ & \multicolumn{2}{|c|}{ Spotfin swamp barb } & \multicolumn{2}{|l|}{ Punti } \\
\hline \multirow[t]{2}{*}{3} & Puntiusticto (Hamilton.1822) & $\begin{array}{l}\text { Bann Ganga near } \\
\text { Village Shahpur, } \\
\text { Sitakhera- } \\
\text { 05exs,Nainpur-02exs }\end{array}$ & Ticto barb & & Pothia & \\
\hline & \multicolumn{6}{|c|}{$\begin{array}{lll}\text { Subfamily } & \text { Cultrinae } \\
\end{array}$} \\
\hline 1 & $\begin{array}{l}\text { Laubucalaubuca (Hamilton. } \\
\text { 1822) }\end{array}$ & \begin{tabular}{l}
\multicolumn{1}{c}{ Ranjitpur } \\
village, Ganga River - \\
07exs
\end{tabular} & Indian glass- $b$ & & Dennahrah & \\
\hline
\end{tabular}




\begin{tabular}{|c|c|c|c|c|}
\hline & \multicolumn{4}{|c|}{ Subfamily Noemachlinae } \\
\hline S.No.. & Species & Locality & Common Name & Local Name \\
\hline \multirow[t]{3}{*}{1} & $\begin{array}{l}\text { Acanthocobitis.botia } \\
\text { (Hamilton. 1822) }\end{array}$ & Nainpur, Luxar-01ex & Loach & \\
\hline & \multirow{2}{*}{\multicolumn{4}{|c|}{ Family $3 \quad$ Cobitidae }} \\
\hline & \multicolumn{2}{|c|}{$\begin{array}{l}\text { Subfamily: Cobitinae } \\
\end{array}$} & & \\
\hline \multirow[t]{2}{*}{1} & $\begin{array}{l}\text { Lepidocephalichthysguntea } \\
\text { (Hamilton.1822) }\end{array}$ & 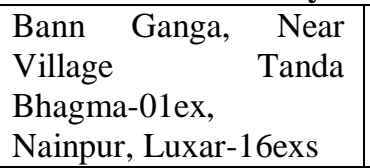 & Loach & Jiwal \\
\hline & \multicolumn{4}{|c|}{$\begin{array}{c}\text { 2. Order } \\
\text { Family } 1 \\
\end{array}$} \\
\hline S.No.. & Species & Locality & Common Name & Local Name \\
\hline \multirow[t]{2}{*}{1} & $\begin{array}{l}\text { Ompokpabda } \\
\text { (Hamilton.1822) }\end{array}$ & $\begin{array}{l}\text { Shahpur (Haridwar and } \\
\text { Around)-01ex }\end{array}$ & Pabada Catfish & Pabdaha \\
\hline & \multicolumn{4}{|c|}{\begin{tabular}{|cc} 
Family 2 & Siluridae \\
\end{tabular}} \\
\hline S.No.. & Species & Locality & Common Nam & Local Name \\
\hline \multirow[t]{3}{*}{1} & Hara jerdoniDay. 1870 & $\begin{array}{l}\text { Nainpur, Luxar, dist. } \\
\text { Haridwar- 02exs }\end{array}$ & Sylhethara & \\
\hline & \multicolumn{4}{|c|}{ 3. Order Perciformes } \\
\hline & \multicolumn{4}{|c|}{ Family $1 \quad$ Nandidae } \\
\hline 1 & $\begin{array}{l}\text { Nandusnandus } \\
\text { (Hamilton.1822) }\end{array}$ & $\begin{array}{lr}\text { Ranjitpur } & \text { village, } \\
\text { Ganga } & \text { River- } \\
\text { 01ex,Bann Ganga, Near } \\
\text { Village Tanda Bhagma- } \\
\text { 03exs, Nainpur, Luxar- } \\
\text { 03exs, }\end{array}$ & $\begin{array}{l}\text { Mottled } \\
\text { Nandus }\end{array}$ & Chambal \\
\hline \multirow[t]{3}{*}{2} & Badisbadis (Hamilton.1822) & Nainpur, Luxar-01ex & \begin{tabular}{|l|} 
Dwarf \\
chameleon \\
fish \\
\end{tabular} & Sumha \\
\hline & \multicolumn{4}{|c|}{ Family 2 Belontiinae } \\
\hline & \multicolumn{4}{|c|}{ Subfamily Trichogasterinae } \\
\hline S.No.. & Species & Locality & $\begin{array}{l}\text { Common } \\
\text { Name }\end{array}$ & Local Name \\
\hline 1 & $\begin{array}{l}\text { TrichogasterfasciataBloch\& } \\
\text { Schneider, } 1801\end{array}$ & $\begin{array}{l}\text { Bann Ganga near Village } \\
\text { Shahpur, Sitakhera- } \\
\text { 09exs,Bann Ganga, Near } \\
\text { Village Tanda Bhagma- } \\
\text { 21ex,Nainpur- } \\
\text { 02exs,Shahpur(Haridwar } \\
\text { and Around)-01ex, } \\
\text { Nainpur, Luxar-01ex }\end{array}$ & $\begin{array}{l}\text { Striped } \\
\text { Gourami }\end{array}$ & Kanghee \\
\hline 2 & $\begin{array}{l}\text { Trichogasterchuna(Hamilton } \\
\text { 1822) }\end{array}$ & $\begin{array}{l}\text { Ranjitpur village, Ganga } \\
\text { River-01ex,Bann Ganga, } \\
\text { Near Village Tanda } \\
\text { Bhagma, Dist. Haridwar- } \\
\text { 08exs, Nainpur } \\
\text { (Haridwar and around)- } \\
\text { 01ex }\end{array}$ & $\begin{array}{l}\text { Sunset } \\
\text { Gourami }\end{array}$ & Kanghee \\
\hline 3 & $\begin{array}{ll}\text { Trichogaster } & \text { latius } \\
\text { (Hamilton.1822) } & \end{array}$ & $\begin{array}{l}\text { Nainpur, Luxar-01ex, } \\
\text { Lalpur, Luxar, dist. } \\
\text { Haridwar-03exs }\end{array}$ & $\begin{array}{l}\text { Dwarf } \\
\text { Gourami }\end{array}$ & Khosti \\
\hline & \multicolumn{4}{|c|}{$\begin{array}{r}\text { Family 3. Channidae } \\
\end{array}$} \\
\hline 1 & Channa & Ranjitpur villae, Ganga & Spotted & Phool dhok \\
\hline
\end{tabular}




\begin{tabular}{|c|c|c|c|c|}
\hline & punctata(Bloch.1793) & $\begin{array}{lr}\text { River } & \text { (Haridwar)- } \\
\text { 01ex,Bann Ganga near } \\
\text { Village } \\
\text { Sitakhera, Shahpur, } \\
\text { Haridwar-01ex, Nainpur } \\
\text { (Haridwar and around)- } \\
\text { 02exs, Nainpur, Luxar- } \\
\text { 21exs }\end{array}$ & Snakehead & \\
\hline & \multicolumn{4}{|c|}{ Family 4. Mastacembelidae } \\
\hline 1 & $\begin{array}{l}\text { Macrognathuspancalus } \\
\text { Hamilton. } 1822\end{array}$ & $\begin{array}{l}\text { Ranjitpur village, Ganga } \\
\text { River (Haridwar)-01ex, } \\
\text { Bann Ganga near Village } \\
\text { Shahpur, Sitakhera, dist. } \\
\text { Haridwar-01ex,Nainpur, } \\
\text { Luxar-01ex }\end{array}$ & $\begin{array}{l}\text { Striped } \\
\text { Spiny eel }\end{array}$ & Bamimachi \\
\hline
\end{tabular}

Table 4:- Species of anurans, Amphibia from the study area

\begin{tabular}{|l|l|l|l|l|}
\hline S.No. & Species & Examples & Locality & Common Names \\
\hline 1 & Fejervarya species & 5 exs & Nainpur & Alpine cricket frog \\
\hline 2 & $\begin{array}{l}\text { Euphlyctis cyanophlyctis } \\
\text { (Schneider) }\end{array}$ & $\begin{array}{l}\text { Hoplobatrachus exs } \\
\text { (Daudin) }\end{array}$ & $\begin{array}{l}\text { Nainpur, Ranjitpur, } \\
\text { Lalpur }\end{array}$ & Common Skittering frog \\
\hline 3 & tigerinus & 3 exs & Nainpur, Bhikampur & Indian bull frog \\
\hline
\end{tabular}

Table 6:- Water analysis of different localities covered during survey (April 2008- Sep.2009)

\begin{tabular}{|c|c|c|c|c|c|c|}
\hline S.No. & Localities & $\begin{array}{l}\text { Mean } \\
\text { Atmospheric } \\
\operatorname{temp}\left(\text { in }^{\circ} \mathbf{C}\right) \\
(12 \text { am to } \\
12.30 \mathrm{pm})\end{array}$ & 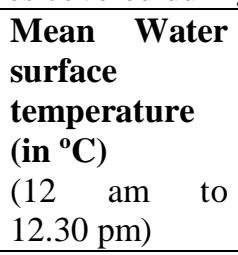 & $\begin{array}{l}\text { pH Mean } \\
\pm \text { SD }\end{array}$ & $\begin{array}{l}\text { EC(in ds/m) } \\
\text { Mean } \pm \text { SD }\end{array}$ & $\begin{array}{l}\text { Dissolved } \\
\text { oxygen }(\mathrm{DO}) \\
\text { in ppm } \\
\text { Mean } \pm \mathrm{SD}\end{array}$ \\
\hline & & $\begin{array}{lr}\mathrm{Sd}: & \text { not } \\
\text { recommended }\end{array}$ & $\begin{array}{l}\text { Sd: not } \\
\text { recommended }\end{array}$ & $\begin{array}{l}\text { Sd: } \mathrm{pH} 6.5 \\
\text { to } 8.5\end{array}$ & $\begin{array}{l}\text { Sd: EC } \\
\text { not } \\
\text { recommended }\end{array}$ & Sd: DO >6 ppm \\
\hline 1 & $\begin{array}{l}\text { Shahpur } \\
\text { (in May) }\end{array}$ & 39 & 31 & $7.02 \pm 0.0$ & $0.588 \pm 0.0$ & $4 \pm 0.01$ \\
\hline 2 & $\begin{array}{l}\text { TandaBhagmal } \\
\text { (in May) }\end{array}$ & 39 & 30 & $7.65 \pm 0.0$ & $0.528 \pm 0.0$ & $3 \pm 0.01$ \\
\hline 3 & $\begin{array}{l}\text { Lalpur (near to } \\
\text { Stone } \\
\text { crusher)(in } \\
\text { June) }\end{array}$ & 39 & 31 & $8.14 \pm 0.1$ & $0.465 \pm 0.1$ & $3 \pm 0.1$ \\
\hline 7 & $\begin{array}{l}\text { Lalpur } \\
\text { (in June) }\end{array}$ & 39 & 30 & $7.31 \pm 0.0$ & $0.203 \pm 0.0$ & $4 \pm 0.02$ \\
\hline 4 & $\begin{array}{l}\text { Nainpur (large } \\
\text { open water } \\
\text { body) (in July) }\end{array}$ & 38 & 32 & $7.26 \pm 0.0$ & $0.257 \pm 0.01$ & $4 \pm 0.01$ \\
\hline 5 & $\begin{array}{l}\text { Nainpur (large } \\
\text { open water } \\
\text { body) (in July) }\end{array}$ & 38 & 30 & $7.35 \pm 0.2$ & $0.288 \pm 0.0$ & $4 \pm 0.01$ \\
\hline 6 & $\begin{array}{l}\text { Shahpur } \\
\text { (in Aug) }\end{array}$ & 34 & 30 & $7.75 \pm 0.0$ & $0.324 \pm 0.01$ & $3 \pm 0.02$ \\
\hline
\end{tabular}




\begin{tabular}{|l|l|l|l|l|l|l|}
\hline 8 & $\begin{array}{l}\text { Ranjitpur (near } \\
\text { to Ganga) } \\
\text { Se(in p) }\end{array}$ & 32 & 25 & $7.03 \pm 0.0$ & $0.191 \pm 0.0$ & $4 \pm 0.02$ \\
\hline
\end{tabular}

Table 7:- Chemical parameters of water analyzed SR Standard Range

SD: Standard value as recommended by BIS 10500 (Bureau of Indian Standards) 1991:

\begin{tabular}{|c|c|c|c|c|c|c|}
\hline S.No & Samples & $\begin{array}{l}\text { Calcium } \\
(\mathrm{ppm}) \\
\text { Mean } \pm \text { SD }\end{array}$ & $\begin{array}{l}\text { Magnesium } \\
(\mathrm{ppm}) \\
\text { Mean } \pm \mathrm{SD}\end{array}$ & $\begin{array}{l}\text { Chloride } \\
(\mathrm{ppm}) \\
\text { Mean } \pm \text { SD }\end{array}$ & $\begin{array}{l}\text { Carbonate } \\
(\mathrm{ppm}) \\
\text { Mean } \pm \mathrm{SD}\end{array}$ & $\begin{array}{l}\text { Bicarbonate } \\
(\mathrm{ppm}) \\
\text { Mean } \pm \text { SD }\end{array}$ \\
\hline & & $\begin{array}{l}\text { SR 15ppm } \\
\text { (Ref NIH } \\
\text { 1987-88) }\end{array}$ & $\begin{array}{l}\text { SR } \\
1-100 p p m \\
\text { (Ref Hem } \\
1989, \\
\text { WHO } \\
1984 \mathrm{a}, \\
1984 \mathrm{~b})\end{array}$ & $\begin{array}{l}\text { SR } \\
<10 p p m \\
\text { (Ref } \\
\text { APHA } \\
\text { 1989; CEC } \\
1976 \text { ) }\end{array}$ & $\begin{array}{l}\text { SR }<10 p p m \\
\text { (Ref. WHO } \\
\text { 1984a, 1984b) }\end{array}$ & $\begin{array}{l}\text { SR < 500ppm } \\
\text { (Ref WHO 1984a, } \\
1984 b)\end{array}$ \\
\hline 1 & Shahpur & $76 \pm 0.01$ & $40.8 \pm 0.0$ & $63.9 \pm 0.02$ & $18 \pm 0.1$ & $335.5 \pm 0.2$ \\
\hline 2 & TandaBhagmal & $68 \pm 0.0$ & $12.0 \pm 0.0$ & $71.0 \pm 0.1$ & nil & $164.7 \pm 0.1$ \\
\hline 3 & $\begin{array}{l}\text { Lalpur (near to } \\
\text { Sone crusher)(in } \\
\text { June) }\end{array}$ & $48 \pm 0.01$ & $33.6 \pm 0.0$ & $63.9 \pm 0.0$ & $15 \pm 0.0$ & $329.4 \pm 0.2$ \\
\hline 4 & $\begin{array}{l}\text { Nainpur (large } \\
\text { open water } \\
\text { body) (in July) }\end{array}$ & $24 \pm 0.0$ & $31.2 \pm 0.1$ & $63.9 \pm 0.2$ & nil & $134.2 \pm 0.0$ \\
\hline 5 & $\begin{array}{l}\text { Nainpur (large } \\
\text { open water } \\
\text { body) (in July) }\end{array}$ & $64 \pm 0.1$ & $12.0 \pm 0.2$ & $56.81 \pm 0.1$ & $18 \pm 0.1$ & $231.8 \pm 0.01$ \\
\hline 6 & $\begin{array}{l}\text { Shahpur } \\
\text { (in Aug) }\end{array}$ & $44 \pm 0.0$ & $48.0 \pm 0.01$ & $78.1 \pm 0.02$ & $15 \pm 0.01$ & $311.1 \pm 0.01$ \\
\hline 7 & $\begin{array}{l}\text { Lalpur } \\
\text { (in June) }\end{array}$ & $40 \pm 0.01$ & $26.4 \pm 0.01$ & $78.1 \pm 0.01$ & $12 \pm 0.01$ & $231.8 \pm 0.01$ \\
\hline 8 & $\begin{array}{l}\text { Ranjitpur (near } \\
\text { to Ganga) } \\
\text { (in Sep) }\end{array}$ & $28 \pm 0.1$ & $24.0 \pm 0.2$ & $78.1 \pm 0.02$ & $6.0 \pm 0.01$ & $164.7 \pm 0.01$ \\
\hline
\end{tabular}

Source: www.bis.org.in 


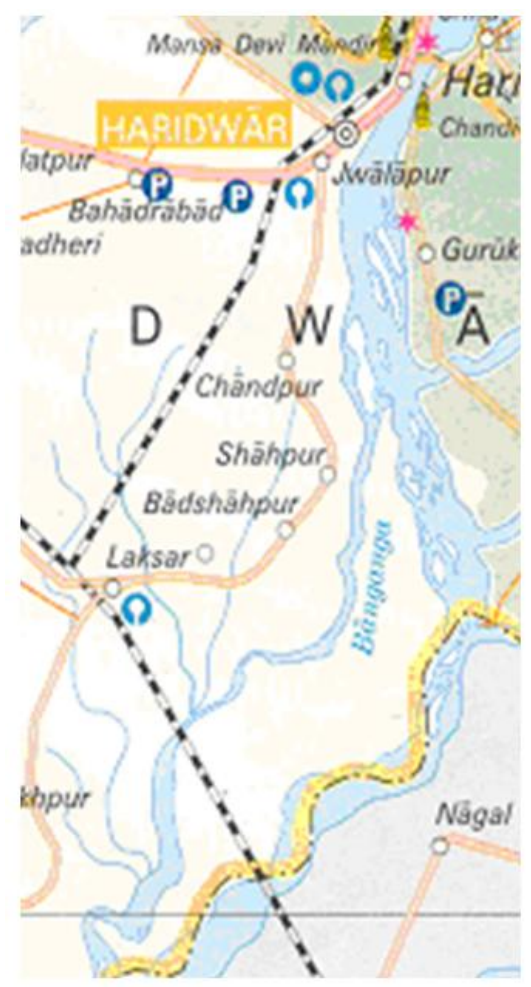

Fig 1:- Map of the study area: Banganga, Near Laksar road. District Haridwar, scale 1:500,000, source : Survey of India, Dehradun.

\section{Localities of study area.}

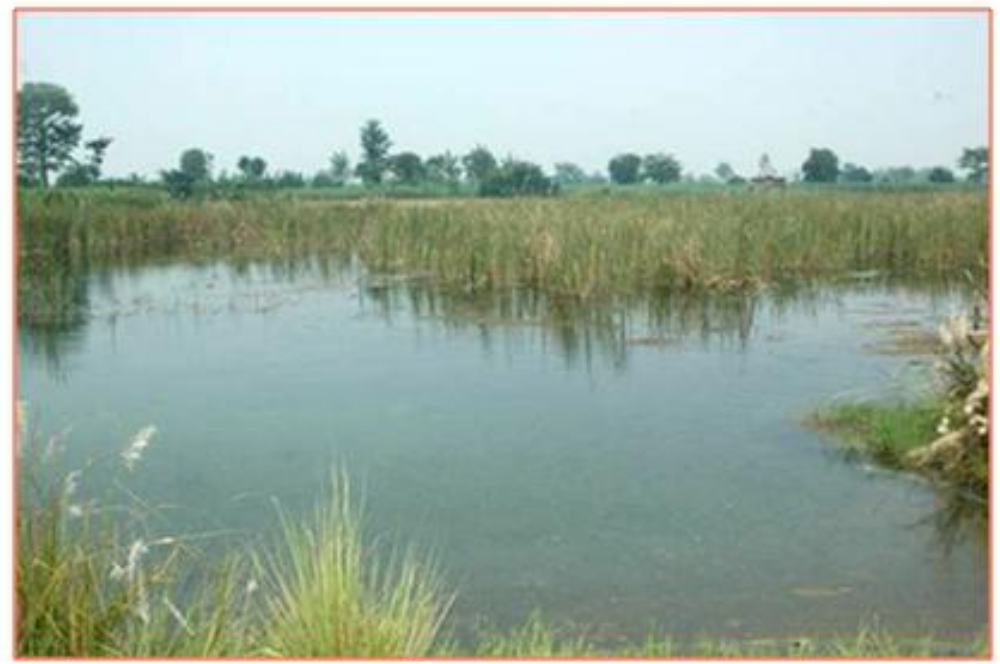

Fig 2:- Lalpur: small water body with stone crusher machine on roadside. 


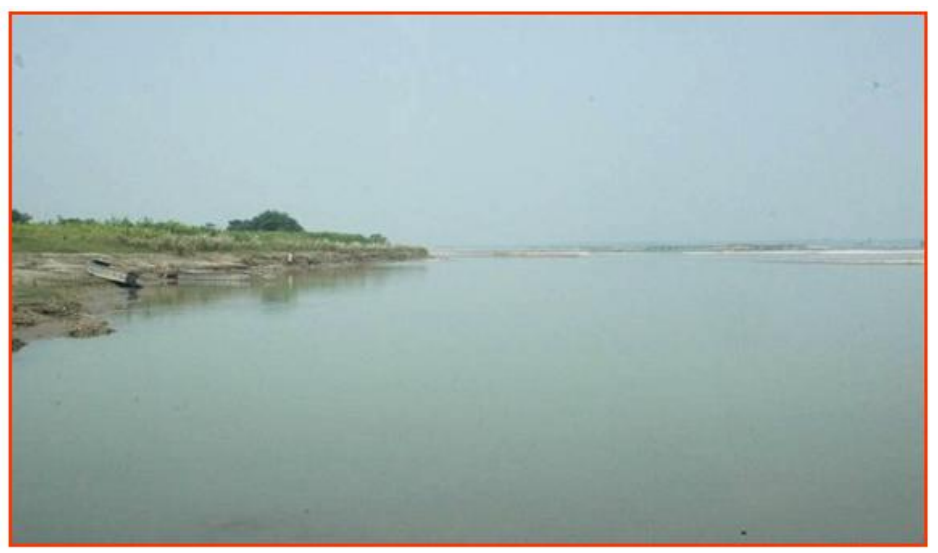

Fig 3:- Ranjitpur: river Ganga; the bank of which are covered with sugarcane plantation.
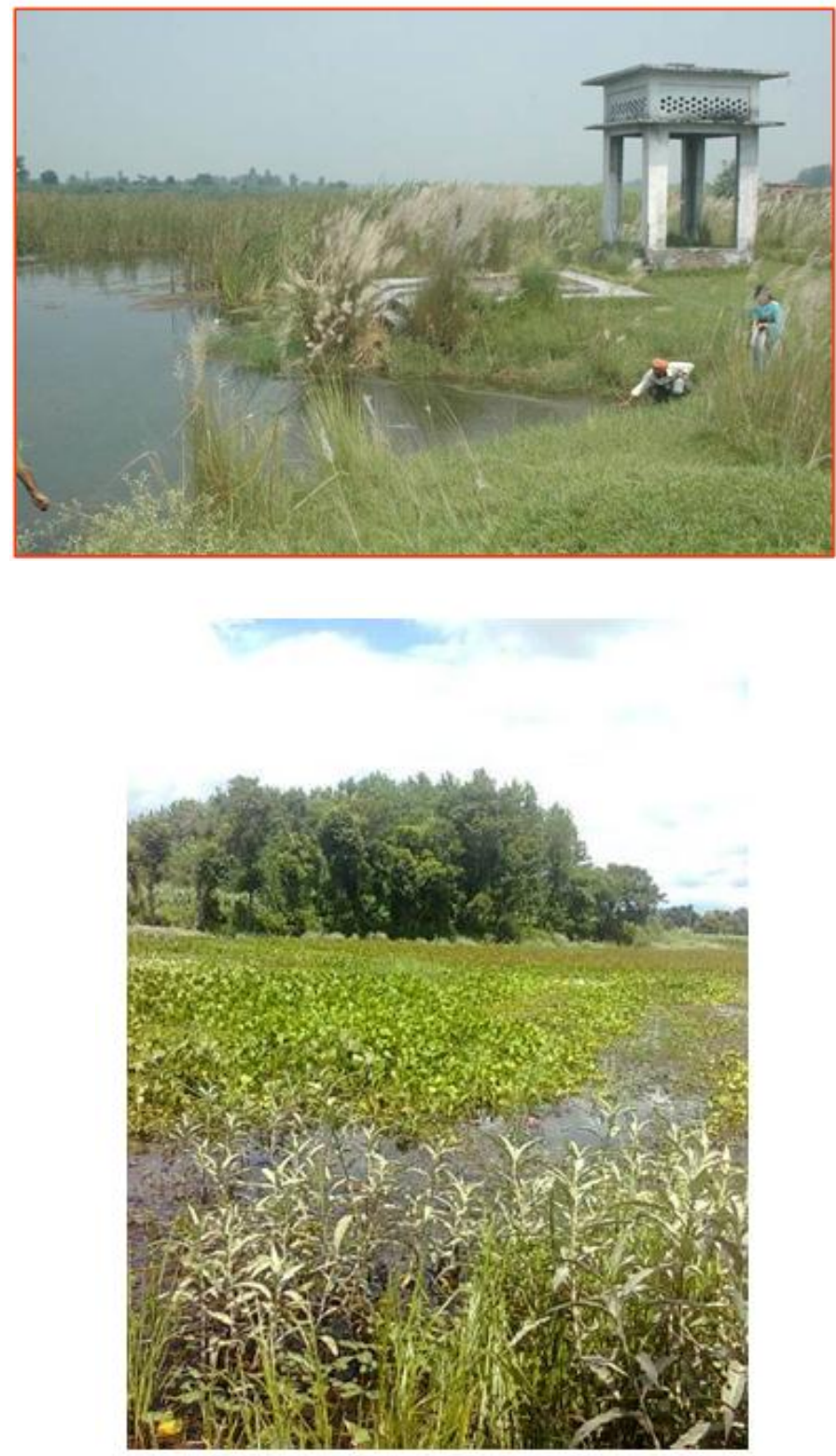

Fig 5:- Bhikampur: infested with weeds, Is a habitat of crocodile. 


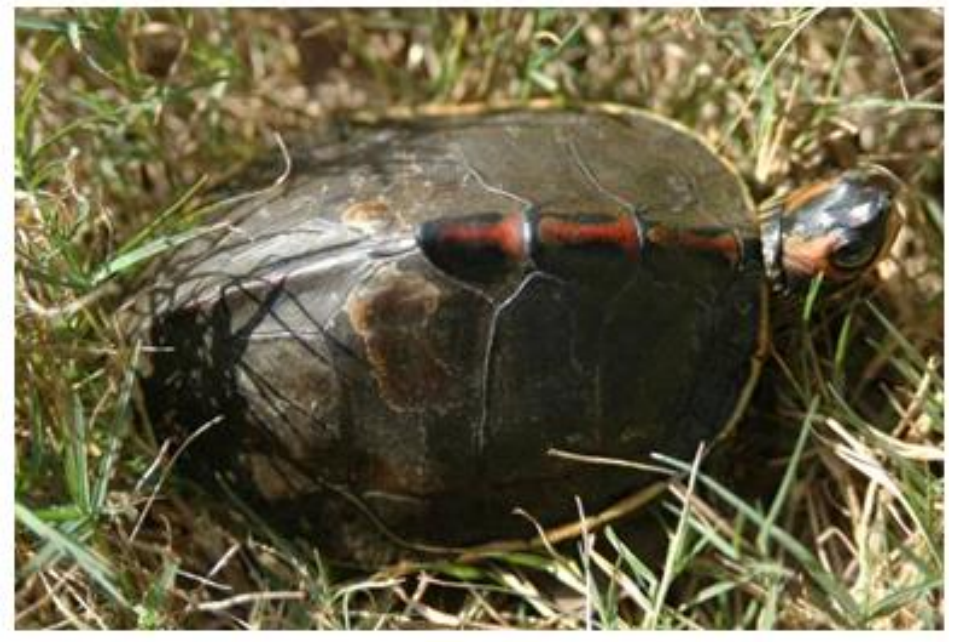

Fig 6:- Pangshura tecta (Gray) Indian roofed turtle.

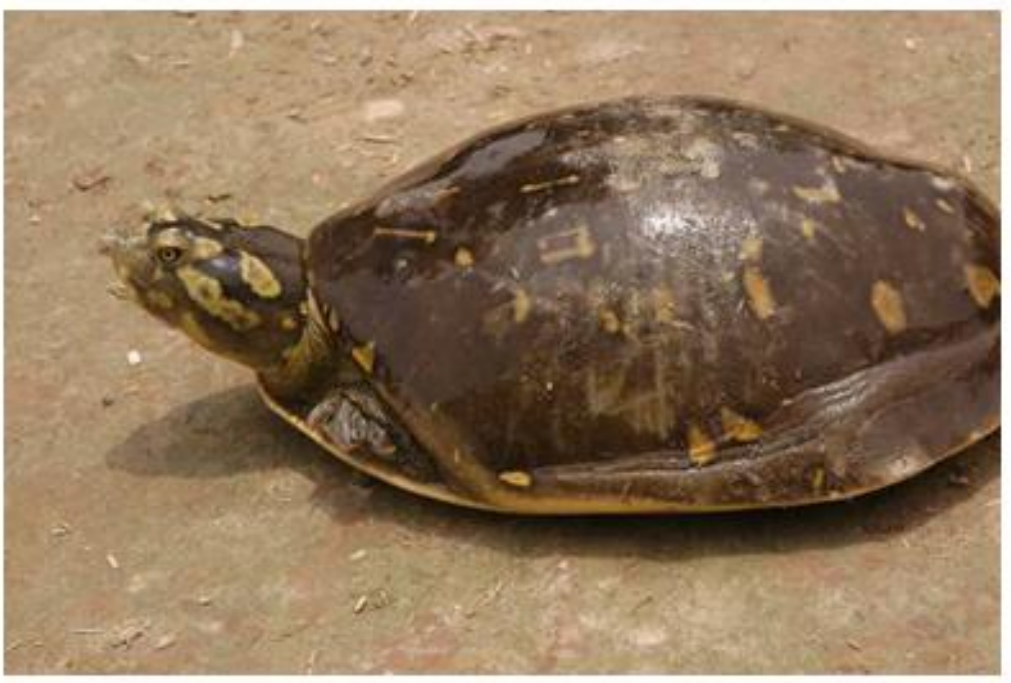

Fig 7:- Leissymus punctataandersoni Flap Shelled turtle.

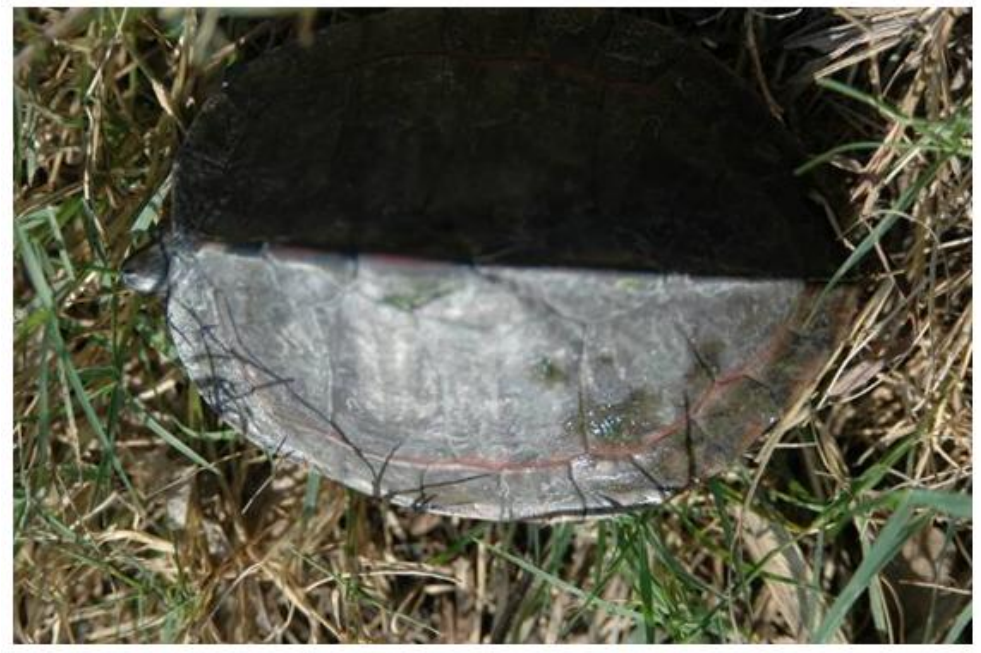

Fig 8:- Pangshura tentoria circumdata, South Indian roofed turtle. 


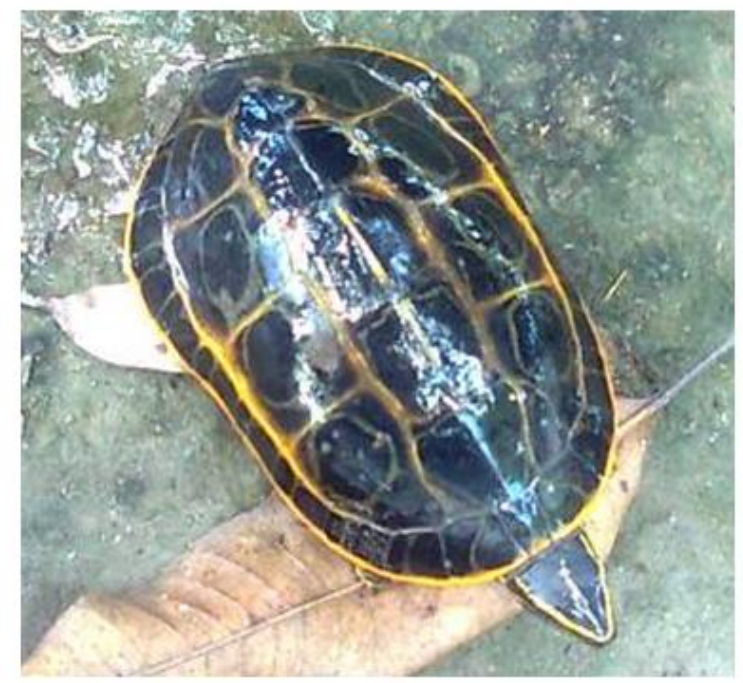

Fig 9:- Morenia petersi ), Indian eyed turtle.

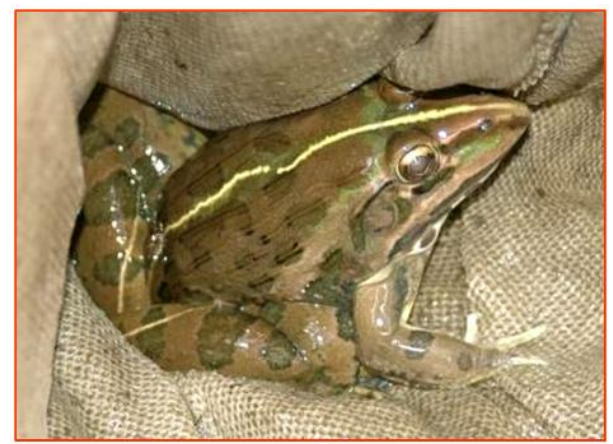

Fig 10:- Hoplobatrachus tigerinus (Daudin), Indian bull frog.

\section{References:-}

1. Adhikari, B.S. and U.M.M.Babu 2008.Floral diversity of Baanganga Wetland, Uttarakhand, India. Check List 4(3): 279-290.

2. APHA. 1989. Standard Methods for the examination of water and wastewater. $17^{\text {th }}$ edition, American Public Health Association, Washington DC. : 1268 .

3. Bahuguna, A. 2010. New distribution record of Moreniapetersii, Herpetological review, 41(2): 242.

4. Bahuguna, Archana. 2010.Reptilia, Fauna of Uttarakhand, State Fauna Series, 18 (1) Director, Zoological Survey of India. : 445-503.

5. Banerjee, S.M. 1967. Water quality and soil of fish ponds in some states of India in relation with production, Indian J. Fish. 14(2): 115-144.

6. Bestemyanov, G.P. andJu.G. Krotov 1985.Maximum Allowable Concentration of Chemicals in the Environment. Khimiya, Leningard, (In Russia)

7. Bhupathy, S. and . Choudhury B.C. (1995).:'Status, distribution and conservation of the Travancore tortoise, Indotestudo forstenii in Western Ghats . J. Bombay Nat. His. Soc expand all journal names 92: 16-21

8. Bureau of India Standard <http://www.robtex.com/gw/www.bis.org.in.htm/

9. CEC (Commission of European Communities) 1976. Council Directive of 18 July 1978 on the quality of fresh waters needing protection or improvement in order to support fish life (78/659/EEC). Official journal L/222,110 .

10. CFH/MCBT (2006). Conservation Action Plan for Endangered Freshwater Turtles and Tortoises of India. Madras Crocodile Bank Trust, Tamil Nadu, South India.

11. Das, I. (1985). Indian turtles: A field guide, World Wildlife Fund- India,Oxford University Press, Calcutta,India. 119 pp. 
12. Das, I. (2002). A photographic guide to snakes and other reptiles of India.New Holland Publishers (UK) Ltd, Garfield House, 86-88 Edgware Road, London W2 2EA,UK.144pp.

13. Devli, L.G. \& B.M. Sharma (2004). Physico chemical analysis of water samples in fresh ponds of Canchipur, Manipur. In: Water pollution Assessment and Management. Daya Publishing House Delhi-110035, 18: 271-275.

14. EIFAC (European Inland Fisheries Advisory Commission).(1964-90).Working Party on Water Quality Criteria for European Freshwater Fish. Water Quality Criteria for European Freshwater Fish, EIFAC Technical Paper Series (various tides), Food and Agriculture Organization of the United Nations, Rome.

15. Frost, Darrel R. (2014). Amphibian Species of the World: an Online Reference. Version 6.0. American Museum of Natural History. Retrieved 6 February 2014.

16. Graf, D.L. \& K.S. Cummings. 2007. Review of the systematics and global diversity of freshwater mussel species (Bivalvia: Unionoida). Journal of Molluscan Studies 73: 291-314.

17. Graf, D.L. 2007. Palearctic freshwater mussel (Mollusca: Bivalvia: Unionoida) diversity and the Comparatory Method as a species concept. Proceedings of the Academy of Natural Sciences 156: 71-88.

18. Haas, F. (1969) Superfamilia Unionacea. Das Tierreich., pp. 1-613, Der Gruyter, Berlin.

19. Hem, J.D. (1989).Study and Interpretation of the Chemical Characteristics of Natural Waters. Water Supply Paper, 2254, $3^{\text {rd }}$ edition, U.S. Geological Survey, Washington D.C. 263pp.

20. Howlader, M. S. A. (2011) Cricket frog (Amphibia: Anura: Dicroglossidae): Two regions of Asia are corresponding two groups. Bonnoprani: Bangladesh Wildlife Bulletin 5 (1-2): 1-7.

21. Husain, A. \& P. Ray (1995).Reptilia, Himalayan Ecosystem Series: Fauna of Western Himalaya, part I, Uttar Pradesh. 1-8: 159-167.

22. ISO (1984). Water quality determination of the sum of calcium and magnesium-EDTA titrimetric method. International Standard ISO 6059-1984 (E), First edition 1984-06-01, International Organization for Standardization.

23. Jackson, M.L. (1962a).Soil chemical analysis. Pub: Constable and Co. Ltd. London : 1-498.

24. Jackson, M.L. (1962b).Soluble salt analysis for soils and water, pp234-241.In :Jackson,M.L.(ed). Soil chemical analysis.Pub: Constable and co. Ltd.: 234-242.

25. Jackson, M.L. (1962c). Dissolved carbonate \& bicarbonate determination, pp 260-271, In : Jackson,M.L.(ed). Soil chemical analysis; Pub: Constable and co. Ltd.

26. Jackson, M.L. (1962d). Chloride determination..In :Jackson,M.L.(ed). Soil chemical analysis; Pub: Constable and co. Ltd.

27. Jackson, M.L. (1962e).Elemental analysis of mineral, colloids,soils,minerals and rocks: Potassium, sodium, calcium and magnesium determination. In: Jackson,M.L.(ed.) Soil chemical analysis; Pub: Constable and co. Ltd. , 285-291..

28. Jairam, K.C. (1999).Freshwater fishes of The Indian Region, Narender publication house, Delhi, 551pp.

29. Moll , E.O.(1985). Freshwater turtles, Sanctuary Asia5, (1).

30. Murthy , T.S.N. \& R.S. Pillai (1986). Turtles and tortoises. In :Ed. T. C. MajupuriaWildlife wealth of India., Tecpress Service, L.P., Thailand.

31. Nesemann, H., Sharma, G. \& R. K. Sinha (2003): The Bivalvia species of the Ganga River and adjacent stagnant water bodies in Patna (Bihar, India) with special reference on Unionacea. Acta Conchyliorum 7: 1-43, Ludwigsburg Wien.

32. Nesemann, H., Sharma, S., Sharma, G. \& R. K. Sinha (2005): Illustrated Checklist of large Freshwater Bivalves of the Ganga River System (Mollusca: Bivalvia: Solecurtidae, Unionidae, Amblemidae). Nachrichtenblatt der Ersten Vorarlberger Malakologischen Gesellschaft 13: 1-51, Rankweil.

33. Nesemann, H., Sharma, S., Sharma, G., Khanal, S.N., Pradhan, B., Shah, D.N. and R.D. Tachamo (2007): Aquatic Invertebrates of the Ganga River System: Volume 1 - Mollusca, Annelida, Crustacea (in part), 263 pp.Published by Hasko Nesemann, Kathmandu, Nepal, ISBN 978-99946-2-674-8.

34. NIH. (1987-1988).Physico-chemical Analysis of Water and Wastewater. National Institute of Hydrology, Roorkee- 247667 (UP), India.

35. Prashad, B. (1922): Observations on the invertebrate fana of the Kumaon Lakes III. The Freshwater Mollusca. Records of the Indian Museum 24: 11-17.

36. Preston, H. B. (1915) Freshwater Gastropoda + Pelecypoda. The Fauna of British India including Ceylon and Burma. pp. I-XI + 244, Francis \& Taylor, London.

37. Ramakrishna and Dey, Anirudh. (2007). Handbook on Indian Freshwater Molluscs 1-399 (Published by the Director, Zoological Survey of India, Kolkata).

38. Rao,R.J.1990.Ecological relationships among freshwater turtles in the National Chambal Sanctuary. Study report mimeo. Wildlife Institute of India.212pp. 
39. Rao,, M.S. and Kumar, R.B. (2002).Ground water conditions in Haridwar district: Geological Society of India, 29: 114-126.

40. Rao , R.J.1985.Management of crocodiles and turtles in Wetland Sanctuaries of India, Tiger paper, 12(4)

41. Rao, R.J. 1998. Status of crocodiles and freshwater turtles in the Chambal river and Ganga river: a comparative analysis, Cobra33, 31-34.

42. Rao, R.J. 2001. Biological resources of Ganga River, India, Herpetobiologia 458:159-168.

43. Rawat, G.S. and Pandav, B. 2006 An ecological assessment of Baan Ganga Wetland, Uttaranchal-a report from Wildlife Institute of India, submitted to Forest Department, Govt. of Uttaranchal :1-83

44. Ray, P. 1998.Systematic studies on the Amphibian fauna of the district Dehradun, Uttar Pradesh, India, Memoirs. (Published-Director Zoological Survey of India), 18 (3) IV+102pp

45. Sharma, R.C.1998.Fauna of India-Reptilia (Testudines and Crocodilia).I, XVI+1-196 (Published-Director, ZSI, Kolkata)

46. Shiva Kumar, K. 2007.Diversity, conservation and sustainable use of fish resources of Banganga wetland, Uttarakhand, India. Indian Forester133(10): 1373-1380.

47. Sinha, R. K., Nesemann, H. and Sharma G. 2003: New Records of Physa n(Gastropoda: Physidae) from Indian subcontinent. Club Conchylia Informationen, Jahrgang 34 (5/6): 5-13, Ludwigsburg-Wien.

48. SNB, DehraDun $7^{\text {th }}$ October 2009, Ganga ke anchal mein magarmach in Rashtriya Sahara, pp3.

49. Subba Rao, N. V. (1989) Freshwater Molluscs of India. Calcutta: Zoological Survey of India. xxiii + 289 pp.

50. Surya Rao, K.V., Mitra, S.C., Maitra, S. \& T. Biswas (1997): Fauna of Delhi. Mollusca 109-134, State Fauna Series 6, Zoological Survey of India.

51. Tikader, B.K. and Sharma, R.C. 1985. Handbook Indian testudines, Edited by the Director Zoological Survey of India, Kolkata pp 156.

52. WHO 1984a. Guidelines for Drinking -Water Quality, 1.. Recommendations. World Health Organization, Geneva, 130pp.

53. WHO 1884b.Guidelines for Drinking - Water Quality. 2. Health Criteria and Other Supporting Information. World Health Organization, Geneva. 